\title{
WISATA KAWASAN PECINAN KOTATUA JAKARTA SUATU TINJAUAN POTENSI PENGEMBANGAN PARIWISATA PERKOTAAN DI INDONESIA
}

\author{
Ary Sulistyo ${ }^{1}$ \\ ${ }^{1}$ Program Studi Manajemen Perhotelan dan Pariwisata, International University \\ Liaison Indonesia \\ email: ary.sulistyo@iuli.ac.id
}

Korespondensi : ary.sulistyo@iuli.ac.id

\begin{abstract}
The function of a city is not only for economic development, but also the city tells the story of the collective memory of its citizens who still exist in their past culture. These culture are the city's cultural resources for tourism. One of them is the Kotatua area of Jakarta, there is a Chinatown area, known as Glodok. This study aims to describe how the Glodok Chinatown cultural area was transformed into an urban tourist destination from the 18th century to the present. This area has many historical attractions or historical tourist destinations such as centers of sacred activity (temples / temples, and churches), as well as profane activity centers (markets, roads / alleys, etc.). Therefore the future development must refer to Law No. 11 of 2010 concerning Cultural Heritage that the use of cultural heritage must be based on protection and development not the other way around. So that it is expected that conservation-based tourism in the Glodok Chinatown area can sustain well without any changes which certainly damage the element of authenticity as Chinatown areas in Jakarta and Indonesia in general.
\end{abstract}

Keywords: kotatua, glodok, city, cultural heritage, tourism

\begin{abstract}
Abstrak
Fungsi sebuah kota tidak hanya untuk perkembangan ekonomi saja, tetapi juga kota bercerita tentang memori kolektif warganya yang masih ada dalam peninggalan masa lalunya. Peninggalan-peninggalan tersebut merupakan sumberdaya budaya kota untuk pariwisata. Salah satunya adalah kawasan Kotatua Jakarta terdapat kawasan pecinan, yang dikenal dengan nama Glodok. Penelitian ini bertujuan mendeskripsikan bagaimana kawasan budaya pecinan Glodok bertransformasi menjadi sebuah destinasi wisata perkotaan di mulai dari abad ke 18 hingga kini. Kawasan ini banyak terdapat historical-site attraction atau destinasi wisata sejarah seperti pusat-pusat aktivitas sakral (klenteng/vihara, dan gereja), maupun pusat kegiatan profan (pasar, jalan/gang, dan lainnya). Oleh karena itu pengembangan ke depan harus mengacu kepada UU No. 11 Tahun 2010 tentang Cagar Budaya bahwa pemanfaatan cagar budaya harus didasarkan pada perlindungan dan pengembangan bukan sebaliknya.Sehingga diharapkan pariwisata berbasis pelestarian (conservation-based tourism) kawasan Pecinan Glodok dapat bertahan (sustain) dengan baik tanpa ada perubahan yang tentunya merusak elemen keasliannya (authenticity) sebagai kawasan pecinan di Jakarta dan Indonesia pada umumnya.
\end{abstract}


Kata kunci: kotatua, glodok, kota, cagar budaya, pariwisata

\section{PENDAHULUAN}

Kegiatan pariwisata atau berwisata merupakan kegiatan yang bisa dibilang salah satu sumber devisa bagi negara yang bersifat non-destructive, artinya tidak merusak secara masif seperti kegiatan berbasis sumberdaya alam lainya dan cenderung meningkat dari tahun ke tahun. Indonesia sudah dianugrahi oleh kekayaan alam dan budaya yang begitu luar biasa, sepatutnya kita bersyukur. Menurut data Passenger Survei Unit tahun 2014 (Thaib, 2016) menyebutkan bahwa pariwisata berbasis budaya termasuk yang terbesar dalam hal portofolio pasar dan wisatawannya yaitu sebesar $60 \%$, wisata alam sebesar $35 \%$, sedangkan man-made tourism (pariwisata binaan) hanya $5 \%$.

Wisata berbasis budaya adalah salah satu jenis kegiatan pariwisata yang menggunakan kebudayaan sebagai objeknya, yang tentunya berbeda dengan wisata alam dan wisata petualangan (Yoeti, 1996). Adapun unsur-unsur kebudayaan secara universal adalah (1) bahasa, (2) sistem pengetahuan, (3) sistem kemasyarakatan dan organisasi sosial, (4) sistem peralatan hidup dan teknologi, (5) sistem mata pencaharian hidup, (6) sistem religi, dan (7) kesenian (Koentjaraningrat, 2002).

Pada dasarnya, wisata berbasis budaya merupakan kegiatan yang menjadikan budaya sebagai objek atau atraksi. Contohnya adalah Pura Tanah Lot beserta masyarakat Hindu di Bali. Pura Tanah Lot yang berada di Beraban, Kediri, Tabanan Bali. Dari pusat Kota Tabanan, lokasinya berjarak sekitar 13 kilometer ke arah selatan. Di sini juga ada budaya Odalan yang diperingati setiap 210 hari sekali oleh masyarakat sekitar. Pura Tanah Lot sebagai salah satu destinasi wisata budaya di Bali selalu ramai dikunjungi oleh para wisatawan, baik lokal maupun mancanegara. Di tempat ini ada dua pura yang berada di atas batu besar. Kedua pura tersebut adalah pura laut yang dijadikan tempat pemujaan dewa penjaga laut. Pura Tanah Lot dan masyarakat pendukungnya yang menjadikan destinasi wisata ini unik.

Adapun di kota besar seperti Jakarta, biasa dijumpai suatu kluster kawasan yang memiliki karakteristik tersendiri yaitu kawasan Pecinan Glodok. Di kawasan ini dapat dikatakan memenuhi elemen-elemen pariwisata seperti 3A: atraksi, amenitas, dan aksesibilitas demikian juga dengan ancillary (tour and travel). Oleh karena itu, kota Jakarta khususnya kawasan pecinan dan 'jejak peninggalannya sejarah' menjadi sumber daya kota seperti yang diungkap oleh G.J. Asworth dan J.E. Turnbridge (2000):

History has become heritage, heritage has become an urban resource, and this resource supplies a major 'history/heritage industry', which shapes not merely the form but the functioning and purpose of the 'commodified' city (Ashworth \& Turnbridge, 2000)

Kawasan Pecinan Glodok sudah jelas memenuhi atraksi wisata karena selain sejarah kawasannya, kawasan ini selalu ramai dikunjungi karena merupakan pusat perdagangan dan perekonomian. Dari segi amenitas kawasan Glodok juga banyak 
terdapat fasilitas penunjang seperti restaurant, hotel, dan fasilitas lainnya. Begitu juga dari segi aksesibilitas, di kawasan ini banyak terdapat fasilitas transportasi yang cukup banyak dan memadai. Kawasan ini dekat dengan Stasiun Kereta Api Jakarta Kota, Halte Busway, dan angkutan kota dan lain sebagainya. Oleh karena itu kawasan ini sangat layak untuk diangkat sebagai destinasi wisata sejarah-budaya (historical-site attraction and destination).

Meski banyak kekurangan dari segi kenyamanan pengunjung serta kebersihan, kawasan ini tetap saja menarik untuk dikaji. Pada penulisan kali ini fokus pada historical-site attraction atau destinasi wisata sejarah. Dengan banyaknya komunitas-komunitas sejarah dan wisata yang menjadikan Kawasan Pecinan Glodok sebagai salah satu destinasi unggulan, tetapi masih kurang dalam pendokumentasian jalur wisata (walking-tour track), peta wisata (tourism map), dan cerita sejarahnya (historical storytelling).

\section{METODE PENELITIAN}

Metode penelitian ini menggunakan pendekatan deskriptif kualitatif. Penelitian deskriptif kualitatif bertujuan untuk mengungkapkan kejadian atau fakta, keadaan, fenomena, variable, dan keadaan yang terjadi. Metode deskriptif merupakan suatu metode dalam meneliti status sekelompok manusia, suatu objek, suatu set kondisi, suatu sistem pemikiran ataupun suatu kelas peristiwa pada masa sekarang. Tujuan dari penelitian deskriptif ini adalah untuk membuat deskripsi, gambaran, atau lukisan secara sistematis, faktual, dan akurat mengenai fakta-fakta, sifat-sifat serta hubungan antar-fenomena yang diselidiki atau dengan kata lain metode deskriptif adalah pencarian fakta dengan interpretasi yang tepat (Creswell, 2014). Adapun tahapan penelitian ini adalah sebagai berikut:

\section{Pengumpulan Data}

Pengumpulan data dilakukan dengan studi kepustakaan dan studi lapangan. Studi kepustakaan dengan melakukan pencarian pada literatur yang relevan, baik buku, jurnal penelitian, berita maupun kegiatan-kegiatan yang dilakukan oleh komunitas pencinta sejarah dan Undang-Undang No 11 Tahun 2010 tentang Cagar Budaya, terutama perihal pelestarian, bahwa pelestarian mecakup perlindungan, pengembangan, dan pemanfaatan.

Studi lapangan dilakukan dengan mengamati dan membandingkan dikategorikan sebagai objek wisata (site attraction) dan atraksi wisata (event attraction). Site attraction disini lebih ditekankan pada man-made attraction atau living heritage yang masih ada hingga kini, yang terbagi menjadi dua kategori, yaitu pusat kegiatan sakral dan pusat kegiatan profan. Pusat kegiatan sakral berupa klenteng, vihara, dan gereja. Sedangkan pusat kegiatan profan yaitu pasar, rukoruko, dan sekolah, serta rumah ber-arsitektur Tionghoa.

\section{Pengolahan Data}

Pengolahan data hasil pengumpulan data disini lebih menekankan pada site attraction bukan event attraction. Site attraction terbagi menjadi beberapa dimensi seperti dimensi bentuk, waktu dan ruang. Dimensi bentuk (form dimension) meliputi 
berbagai macam tinggalan atau objek berupa bangunan dan struktur yang masih memperlihatkan potensi kesejarahan dan potensi kepariwisataan. Dimensi waktu (time dimension) mencoba melihat dari aspek kronologi waktu kenapa dan mengapa suatu objek memiliki nilai penting untuk dapat dikembangkan menjadi sebuah destinasi. Lalu kemudian dimensi ruang (space dimension) lebih menekankan pada lokasi dimana sebuah destinasi ditemukan.

\section{Interpretasi Data}

Interpretasi data merupakan salah satu ciri khas dari penelitian kualitatif dimana tidak menguji hipotesa namun lebih kepada analogi. Analogi didasarkan pada keberlanjutan bukti sejarah suatu daerah/kawasan berdasarkan data-data seperti survey dan observasi serta peta-peta lama, toponimi, struktur dan bangunan yang masih ada, maupun struktur dan kawasan yang masih memperlihatkan bukti-bukti kesinambungan tadi.

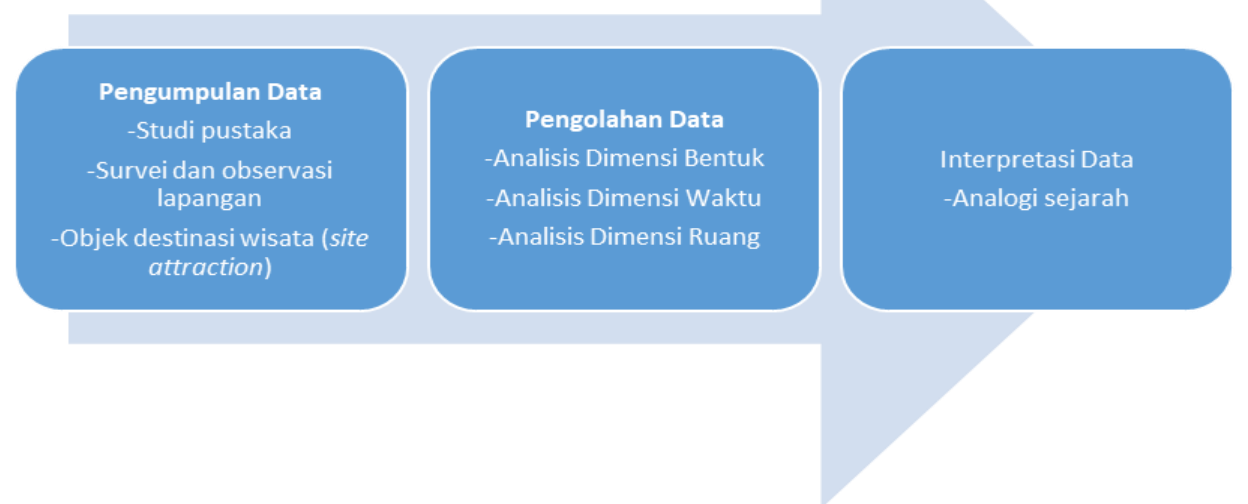

Gambar 1. Tahapan Penelitian

\section{PEMBAHASAN}

\section{Wisata Kota (Urban Tourism)}

Wisata kota (urban tourism) menjadi wacana mulai tahun 1980an terutama negara-negara di Amerika Serikat dan Kanada (Anglo-American) dimana pariwisata dihubungkan dengan rekreasi ke luar kota atau daerah pedesaan serta kontak langsung dengan alam. Namun sebaliknya dalam pandangan visi industrialis, kota dipahami sebagai tempat untuk kerja, perdagangan, dan pemerintahan (Pasquinelli \& Bellini, 2017). Sejak awal tahun 1980 juga minat pada wisata perkotaan meningkat, seiring juga perkembangan kawasan kota sendiri selain sebagai fungsi ekonomi dan bisnis.

Contohnya Kota Bandung memiliki cerita tersendiri sebagai kota wisata (tourism city). Pada awal tahun 1920-an, Bandung dikenal dengan wisata alam, dan wisata budaya, ketika para bangsawan Belanda yang tinggal di Jakarta (Société Concordia) pergi 
berlibur ke Bandung. Kemudian evolusi urban tourism yang dimulai sekitar tahun 1980an; Bandung lebih di kenal sebagai kota pariwisata (khususnya wisata belanja), yang ditandai dengan munculnya Mall pertama, yaitu BIP (Bandung Indah Plaza), distro dan factory outlet. Bandung berubah menjadi tempat wisata kuliner dan wisata malam pada tahun 2000 hingga 2010. Perkembangan aktivitas-aktivitas modern, seperti: pub, kafe, nightlife, dan arena bermain seperti Disneyland juga turut mewarnai perkembangan kepariwisataan di Kota Bandung (Wardhani, 2012).

\section{Sejarah Pecinan Kotatua Jakarta}

Sejarah kawasan pecinan (china town) di Jakarta sudah ada berabad-abad. Tidak hanya sebagai Kota Kolonial namun juga Kotatua Jakarta menunjukkan perkembangan dan evolusi dari kota tradisional hingga kota colonial di belahan dunia timur dan sebagai kota multi-etnik yang berakulturasi dan kemudian dibuat sesuai dengan tata kota di Eropa pada abad ke 18 Masehi (Haris, 2007). Kotatua Jakarta begitu juga dikenal dengan nama Old-Town Jakarta atau Oude Batavia hanya berukuran $1.3 \mathrm{~km}^{2}$ yang melintang dari arah Utara Jakarta dan Jakarta Barat secara administratif dan secara astronomis berlokasi pada $6^{\circ} 08^{\prime} 05^{\prime \prime}$ LS $106^{\circ} 48^{\prime} 48^{\prime \prime}$ BT. Kotatua juga memiliki nama "Jewel of Asia" dan "Queen of The East" pada awal abad ke $17 \mathrm{M}$ oleh para penjelajah dan pelaut dari Eropa. Kotatua Jakarta atau Batavia merupakan pusat perdagangan karena lokasinya strategis. Pada tahun 1522, Fatahilah dikirim oleh Sultan Demak untuk menyerang pelabuhan Sunda Kelapa (sebelumnya sebagai pelabuhan Kerajaan Hindu Sunda Pajajaran) yang kemudian diberi nama Djayakarta. Kota Djayakarta sendiri hanya 15 Ha dan memiliki pelabuhan tradisional dan merupakan kota yang direncanakan oleh penguasa lokal. Pada tahun 1619, VOC (Vereenigde Oostindische Compagnie) sebuah perusahaan dagang milki Belanda menghancurkan kota Djayakarta dibawah pimpinan Jan Pieterzoon Coen, dan setahun kemudian VOC membangun kota bernama Batavia.

Pada tahun 1635, kota berkembang ke arah barat tepi Kali Ciliwung direruntuhan Kota Djayakarta. Kota ini didesain dan dilengkapi dengan kastil (Kasteel Batavia), tembok kota, dan kanal-kanal. Kemudian kota disempurnakan pada tahun 1650 dan Batavia menjadi ibukota VOC di wilayah Hindia Timur. Perkembangan dan pertumbuhan penting kota Batavia sejak 1645 tidak bisa melupakan jasa Phoa Bing Am, seorang kapten Cina (Kapitein der Chinezen) yang membangun kanal. Kanal-kanal dibangun atas inisiatifnya pada tahun 1648 untuk melancarkan jalur kayu ke daerah pembuatan kapal dan ke Pelabuhan Sunda Kelapa. Dengan adanya kanal tersebut, daerah sepanjang alirannya berkembang menjadi pemukiman yang didominasi oleh imigran Cina dan Eropa. Kota Batavia termasuk daerah yang sangat disukai imigran Cina sejak awal abad XIX. Para imigran tersebut berperan sebagai pedagang dan melayani jasa sebagai pialang antara pedagang pribumi dari pedalaman ke pasar internasional Asia Tenggara. Namun demikian, tumbuhnya populasi Cina di Batavia menimbulkan banyak kekerasan. Belanda berusaha membatasi tumbuhnya penduduk Cina dengan membuat peraturan imigrasi di kota-kota pesisir. Pemberontakan orang-orang Cina meletus, berakibat pembunuhan 5000 orang Cina pada tahun 1740 atas perintah Gubemur Jenderal Adrian Valckenier (1695-1751). Sejak pembunuhan massal di halaman belakang 
Balai Kota Batavia itu, wajah VOC semakin buruk. Situasi ini diperburuk dengan buruknya kondisi kesehatan kota dengan meluasnya wabah malaria, kolera, dan pes di kawasan muara sungai Ciliwung dan sekitarnya (Tim Ahli Cagar Budaya Provinsi DKI Jakarta, 2015).

Setelah peristiwa 1740 tersebut, banyak orang-orang Cina mulai ditempatkan di sekitaran kota (ommelanden) hingga dibuatkan satu kawasan sendiri yang dikenal dengan mana Petak Sembilan, mengacu pada peta lama dinamakan Chine Kwartier. Seiring dengan pembubaran VOC pada tahun 1795an Kota Batavia masih berkembang namun sudah tidak sehat. Hingga penguasaan Perancis atas Belanda, Kota Batavia dipimpin oleh Gubernur Jendral H.W. Daendels pada tahun 1808-1811 pada waktu itu membongkar sebagian tembok kota dan kastil untuk pembangunan kota yang lebih ke selatan atau Weltevreden, kini daerah sekitar Gambir.

\section{Pecinan Jakarta Sebagai Potensi Pariwisata Kota}

Kawasan Pecinan berkembang dan memiliki sejarah yang panjang seiring dengan pertumbuhan kota-kota praindustri terutama kota-kota kerajaan lokal (Lombard, 2005) yang kemudian mengalami kolonialisasi Belanda pada abad 17$20 \mathrm{M}$. Atas dasar ini, kota Batavia mencapai puncaknya pada abad ke $18 \mathrm{M}$ begitu juga makin banyaknya migran dari daratan Cina yang datang dan berakulturasi dan berasimiliasi dan membentuk Kawasan Pecinan (Glodok) sekarang.

Berdasarkan hasil survei dan obeservasi, penelitian ini memfokuskan pada kawasan Glodok, Kecamatan Tamansari, Jakarta Barat saja karena dianggap bahwa karakter historis kawasan Glodok sangat potensial untuk dikembangkan sebagai destinasi wisata sejarah (historical site attraction). Adapun hasil survey dan obeservasi, termasuk wawancara tentang potensi-potensi dipusatkan di kawasan Glodok dibagi menjadi dua (2) yaitu pusat kegiatan sakral dan pusat kegiatan profan.

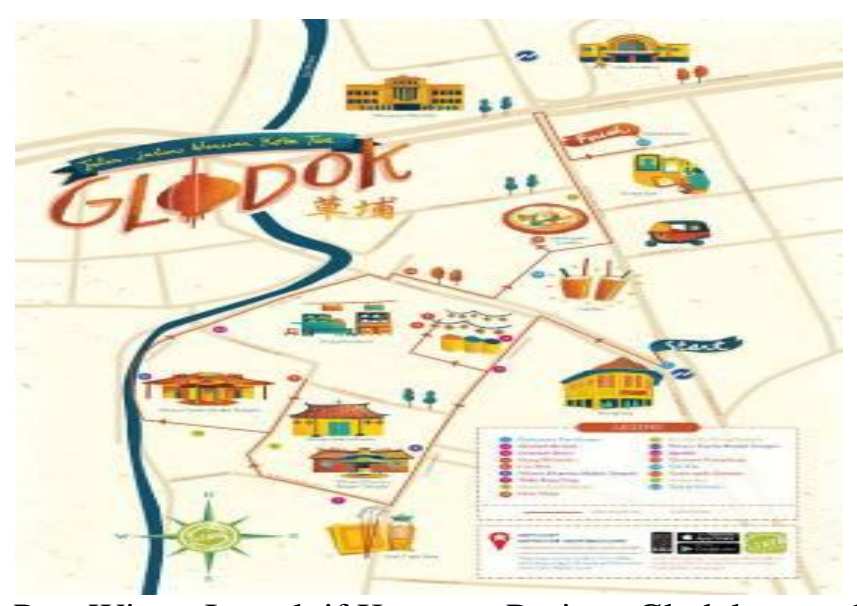

Gambar 2. Peta Wisata Interaktif Kawasan Pecinan Glodok yang dibuat oleh iDiscovery (Sumber: Astrid Prasetianti, Glodok and Kotatua Map for iDiscovery, https://www.behance.net/gallery/53075243/Kota-Tua-Glodok-Map-for-iDiscover) 


\section{Pusat Kegiatan Sakral}

Adapun pusat kegiataan sakral diwakili oleh bangunan klenteng/vihara dan gereja. Berikut beberapa Klenteng/Vihara yang ada di Kawasan Pecinan, diantaranya adalah:

\section{Klenteng/Vihara}

Klenteng dan vihara di kawasan pecinan Glodok dapat dibilang banyak, selain itu terdapat pula rumah abu marga, khusus untuk marga tertentu atau keluarga. Ada sekitar 5 klenteng/vihara besar di kawasan pecinan Glodok, diantaranya adalah Vihara Budhi Dharma/Klenteng Li Tie Guai, Vihara Ariya Marga/Klenteng Nan Jing Miao, Klenteng Toa Se Bio, dan Klenteng Djin De Yuan.

\section{Vihara Budhi Dharma/Klenteng Li Tie Guai}

Klenteng Dharma Bakti terletak di Jalan Perniagaan Timur No. 69 RT 7/RW 1, Kelurahan Roa Malaka, Kecamatan Tambora, Jakarta Barat. Klenteng ini berlokasi di depan Toko Obat Lay An Tong. Klenteng Li Tie Guai didirikan oleh perkumpulan Toa Pe Kong Li Tiat Kway pada sekitar tahun 1812. Menurut Lombard dan Salmon (1985), klenteng Li Tie Guai merupakan satu-satunya bangunan klenteng pada masa itu karena Kota Batavia sering dilanda kekacauan akibat pemerintahan yang silih berganti dan masa pendudukan Inggris-yang dimulai sejak 1811. Klenteng ini pada mulanya merupakan tempat peribadatan bagi perserikatan ahli obat-obatan. Seiring waktu, klenteng ini juga dikunjungi oleh sekelompok pandai besi keturunan Hakka (Tim Direktorat Purbakala, 2000: 73-74).

Klenteng Li Tie Guai ini merupakan dua dari sembilan klenteng yang dibaktikan kepada salah satu dari "Delapan Hyang Mulia" atau Ba Xian, yaitu, $L i$ Tie Guai atau "Li, si tongkat besi". Dia dianggap sebagai dewa pengobatan dan dewa pelindung bagi para pembuat obat. Li Tie Guai biasanya ditampilkan dengan sebagai seorang pengemis yang berpakaian compang-camping, pincang, dan membawa tongkat besi, sambil menjinjing sebuah buli-buli merah. Di samping Dewa $\mathrm{Li}$ Tie Guai, di ruang suci utama atau altar utama terdapat dewa pendampingnya, Hoe Sian Ku atau Dewa Kebajikan. Di kedua klenteng tersebut nama dewa diawali dengan huruf xian shi, artinya mantan guru. Hal ini menunjukkan bahwa pada mulanya klenteng ini milik persekutuan-persekutuan (Tim Direktorat Purbakala, 2000 ; Salmon dan Lombard, 2003).

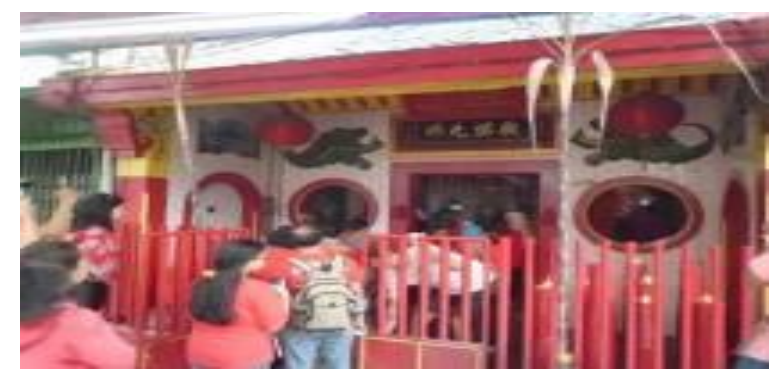


Gambar 3. Klenteng Li Tie Guai (tampak depan) dengan dewa utama Li Tie Guai yang dianggap sebagai dewa kesembuhan

\section{Vihara Arya Marga/Klenteng Nan Jing Miao}

Klenteng ini terletak di Jalan Perniagaan Gang Lamceng No. 6, Kelurahan Tambora, Kecamatan Tambora, Jakarta Barat. Lingkungan Vihara Arya Marga ini berada di sebuah gang yang bernama Lamceng dan di depan gang terdapat tulisan "Wihara Ariya Marga". Klenteng ini berada sekitar $20 \mathrm{~m}$ dari Jalan Perniagaan Raya. Nama lain klenteng ini adalah Kwan Tee Bio atau Lamceng Tee Koen. Sama seperti klenteng lainnya, yaitu bentuk atap dengan hiasan bubungan atapnya berupa hewan-hewan yang dicat merah dan kuning. Keseluruhan bangunan masih tampak asli namun sudah banyak perubahan disana-sini. Menurut beberapa keterangan, bahwa klenteng didirikan pada tahun 1824 di atas tanah sumbangan dari Kapiten Tee Liong Hwie. Klenteng yang didirikan pada abad ke-19 ini, dahulu merupakan klenteng kongsi dagang. Sampai sekarang, klenteng tetap terbuka untuk semua umat yang akan melakukan ibadah (Tim Direktorat Purbakala, 2000).

Klenteng Nan Jian Miao dibangun pada tahun 1824 di Gang Lamceng. Klenteng ini dipersembahkan kepada Guan Di. Dewa Kwan Kong atau Guan Di adalah seorang panglima perang kenamaan yang hidup pada zaman San Guo (221269 M). Dewa Kwan Kong hingga kini dipuja karena kejujuran dan kesetiaannya. Dia adalah lambang atau tauladan ksatria sejati yang selalu menepati janji dan setia pada sumpahnya. Selain itu Dewa Kwan Kong dipuja sebagai dewa pelindung perdagangan, pelindung kesusastraan dan dewa pelindung rakyat dari malapetaka yang mengerikan.

Klenteng ini didirikan oleh seorang Kapitan Cina asal Nanjing, Kabupaten Zhangzhou (Fujian) yang bernama Tee Liong Hwie. Nama inilah yang menerangkan nama klenteng tersebut. Kapitan itu meninggal dunia tanpa keturunan. Maka, kekayaannnya dipergunakan untuk mendirikan sebuah klenteng, agar supaya upacara penguburannya terjamin. Dia menetapkan, agar jenazahnya dimakamkan di dalam klenteng itu. Peraturan itu berlangsung terus selama satu setengah abad. Para penghuni rumah-rumah dipelataran depan klenteng itu masih menghormati sang kapitan pada hari-hari tertentu (Salmon dan Lombard, 2003).
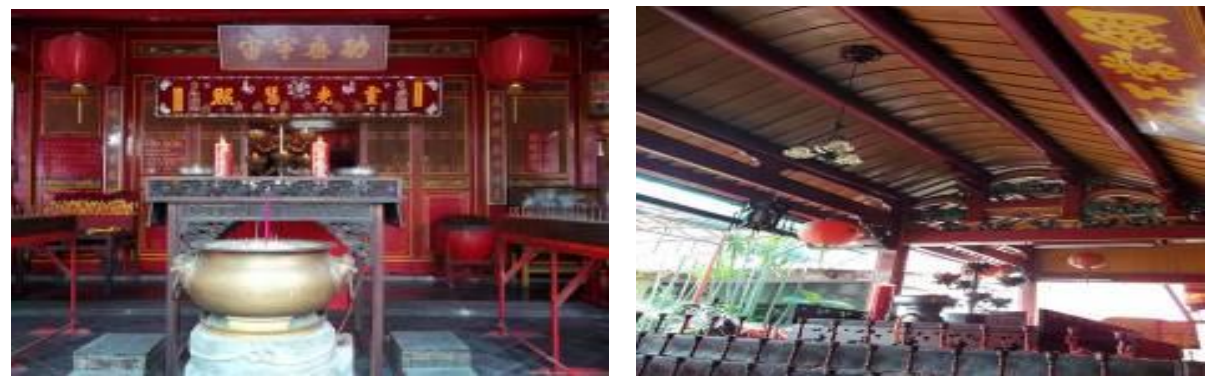

Gambar 4. Altar pemujaan dewa di Klenteng Nan Jing Miao (Kiri), Struktur atap altar pemujaan dewa di Klenteng Nan Jing Miao (Kanan).

Vihara/Klenteng Toa Se Bio 
Klenteng Toa Se Bio berada di Jalan Kemenangan III No. 48 RT 11/RW 3, Kelurahan Glodok, Kecamatan Tamansari, Jakarta Barat. Klenteng Feng Shan Miao dibangun pada sekitar tahun 1751. Berdasarkan keberadaan prasasti kayu tertua yang ditemukan di klenteng Feng Shan Miao (Salmon dan Lombard, 2003). Klenteng ini dibangun sebagai tempat sembahyang para pedagang yang berasal dari Changtai, Kabupaten Zhangzhou, Propinsi Fujian. Dewa utama yang disembah dalam klenteng ini ialah $D a$-shi, yang berarti Utusan Agung. Da-shi merupakan dewa yang sangat dihormati di distrik Changtai dan Tong'an. Penyembahan terhadap Da-shi jarang dilakukan di klenteng daerah 'Lautan Selatan', kecuali di Tegal dan Singapura. Selain ditujukan sebagai tempat sembahyang, klenteng Feng Shan Miao juga menjadi pusat kongsi para pedagang (hui-guan).

Dahulu tanah ini milik Tuan Tanah Marga Tan, pada waktu membeli tanah ini, bangunan klenteng sudah berdiri. Nama asli klenteng adalah Feng Shan Miao atau Da Shi Miao. Kemudian tahun 1980 diganti namanya menjadi Vihara Dharma Wijaya, selanjutnya diubah menjadi Vihara Dharma Jaya Toa Se Bio, akhirnya menjadi Vihara Dharma Jaya. Tahun 1988 dilakukan penambahan bangunan baru, ke arah samping kanan, kiri, belakang dan atas (Direktorat Purbakala, 2000). Berikutnya tahun 1900 dipugar. Sekarang keadaannya terawat dan dikelola oleh Yayasan Vihara Dharma Jaya Toa Se Bio.

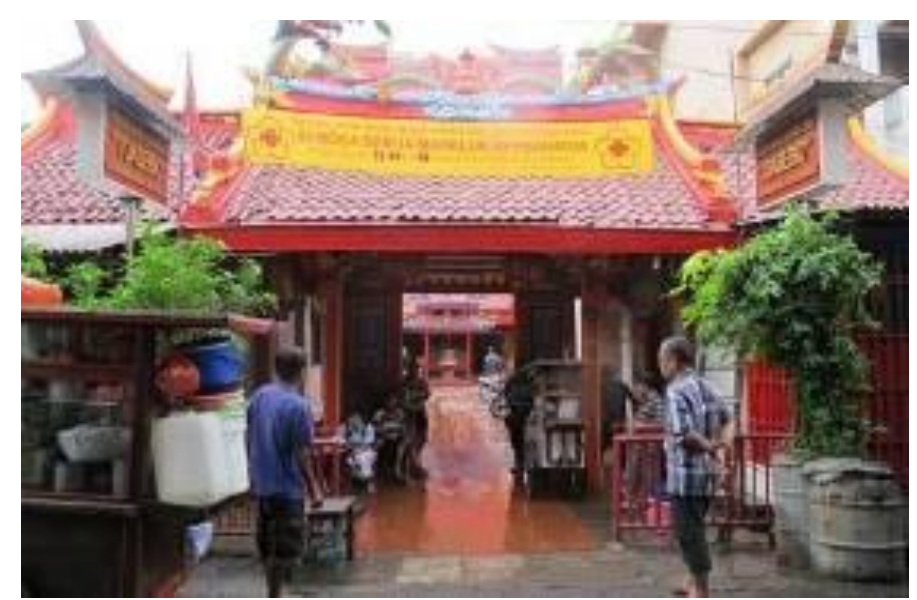

Gambar 5. Tampak Muka Gerbang kecil klenteng Toa Se Bio pada tahun 2017

\section{Vihara Dharma Bakti/Klenteng Kwan Im Teng}

Vihara Dharma Bakti atau Klenteng Kwan Im Teng terletak di Jalan Kemenangan III No. 13, Petak Sembilan RT 01/RW 06, Kelurahan Glodok, Kecamatan Tamansari, Jakarta Barat. Klenteng Jin De Yuan diperkirakan dibangun pada pertengahan abad ke-17 dan merupakan klenteng yang tertua di Jakarta. Bangunan klenteng dipugar total pada tahun 1755 oleh seorang Kapiten Tionghoa Oei Tsi Lauw sehingga kemudian menamai klenteng ini dengan nama Jin De Yuan (berarti Kebajikan Emas). Pemugaran pertama kali ini dilakukan setelah peristiwa kebakaran yang melanda bangunan klenteng pada tahun 1740 (Direktorat Purbakala, 2000; Salmon dan Lombard, 2003; Heuken, 2016). 

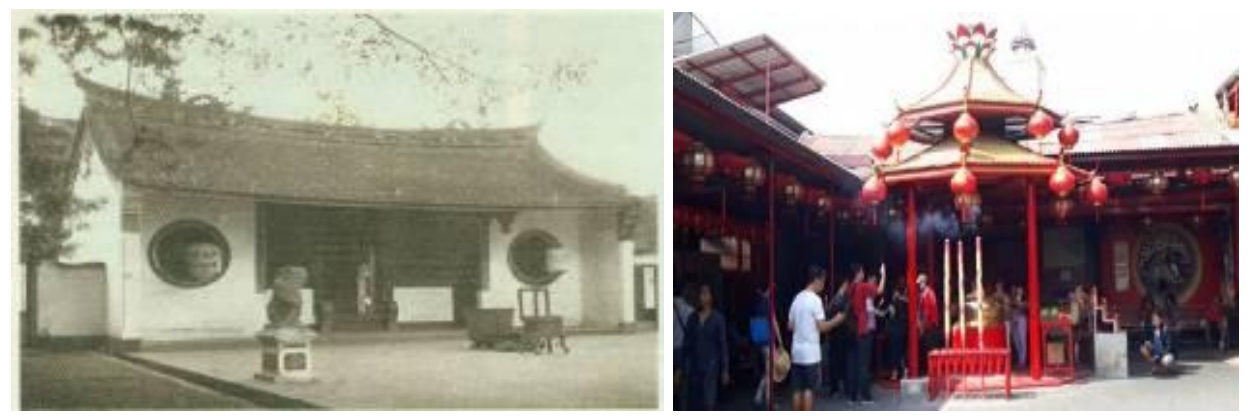

Gambar 6. Foto Klenteng Jin de Yuan pada tahun 1920an (Sumber: Heuken, 2016: 254) (Kiri), Foto Klenteng tahun 2018 pasca kebakaran pada tahun 2015 (Kanan).

\section{Gereja}

Ada 2 gereja di kawasan Pecinan Glodok yang bisa dijadikan destinasi wisata budaya, yang pertama adalah Gereja Kristen Indonesia Perniagaan dan yang kedua adalah Gereja Santa Maria De Fatima.

\section{Gereja Kristen Indonesia Perniagaan}

Gereja Kristen Indonesia Perniagaan Jakarta yang juga dikenal dengan nama gereja "Salib Tiga." Menurut catatan sejarah ternyata GKI Perniagaan salah satu gereja yang tertua di Jakarta. Sebenarnya dahulu GKI Perniagaan menyebut dirinya sebagai gereja: "Tiong Hoa Kie Tok Kauw Tong" atau masyarakat pada zaman dahulu juga menyebut sebagai "gereja Patekoan" karena letak tempatnya di J1. Patekoan (sekarang Jl. Perniagaan). Menurut A. Heuken SJ (2003), GKI Perniagaan telah dirintis sejak tahun 1868 yang waktu itu telah dimulai di Jl. Pagerman (dekat Jl. Kopi) oleh seorang penginjil yang bernama Gan Kwee. Penginjil Gan Kwee sebenarnya berasal dari Amoy (Xianmen), Tiongkok (Heuken, 2003).

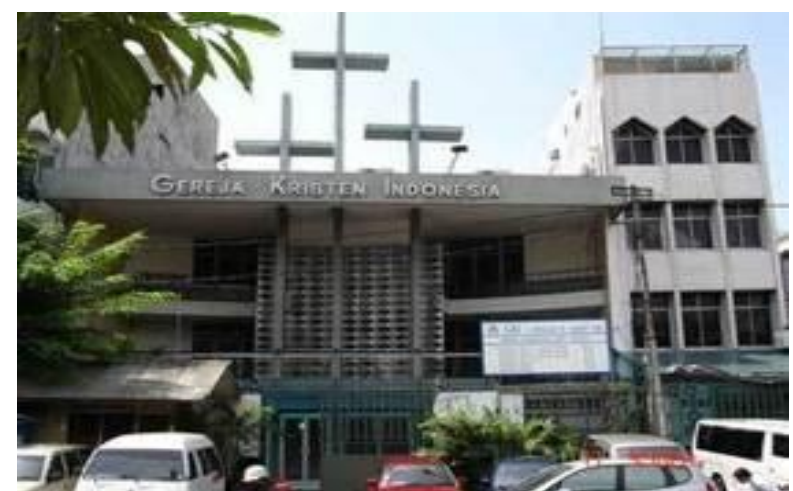

Gambar 7. Gereja Kristen Perniagaan atau yang dikenal dengan nama Gereja Salib

Tiga atau Gereja Patekoan

\section{Gereja Santa Maria De Fatima}


Sejarah Gereja Santa Maria De Fatima terletak di Jalan Kemenangan III No. 47, Kelurahan Glodok, Kecamatan Tamansari, Kota Jakarta Barat, Provinsi DKI Jakarta. Gereja ini sekarang dikelola oleh Paroki Toasebio. Pada abad ke 18, kawasan ini masih merupakan kawasan pemukiman dan perkebunan di luar tembok kota (Ommelanden). Kompleks Gereja Santa Maria de Fatima ini semula digunakan untuk tempat tinggal seorang Tionghoa kaya raya. Pemilik tanah tempat gereja ini berdiri antara lain Mayor Tan Jing Tiat, Tjiu Bok Liem, lalu diwariskan kepada Tjiu Koen Gie, dan terakhir diwariskan kepada Tjiu Tiang Ie. Keturunan Tjiu Pek Ie yang tinggal di belakang gereja adalah Tjiu Pek Tiam. Tahun 1953, dibelilah sebidang tanah seluas 1 hektar untuk digunakan sebagai kompleks gereja dan sekolah, dari seorang kapitan (pemimpin keturunan Tionghoa pada Zaman Penjajahan Belanda) bermarga Tjioe. Bangunan ini dibeli oleh Wilhelmus Krause van Eiden S.J. seorang keturunan Belanda. Pada 1954, tanah dan bangunan itu resmi menjadi milik gereja. Di atas tanah itu berdiri sebuah bangunan utama dengan dua bangunan mengapit bangunan utama. Bangunan utama ini memiliki dua buah patung singa yang melambangkan kemegahan bangsawan Cina (Oesman dkk, 2009).
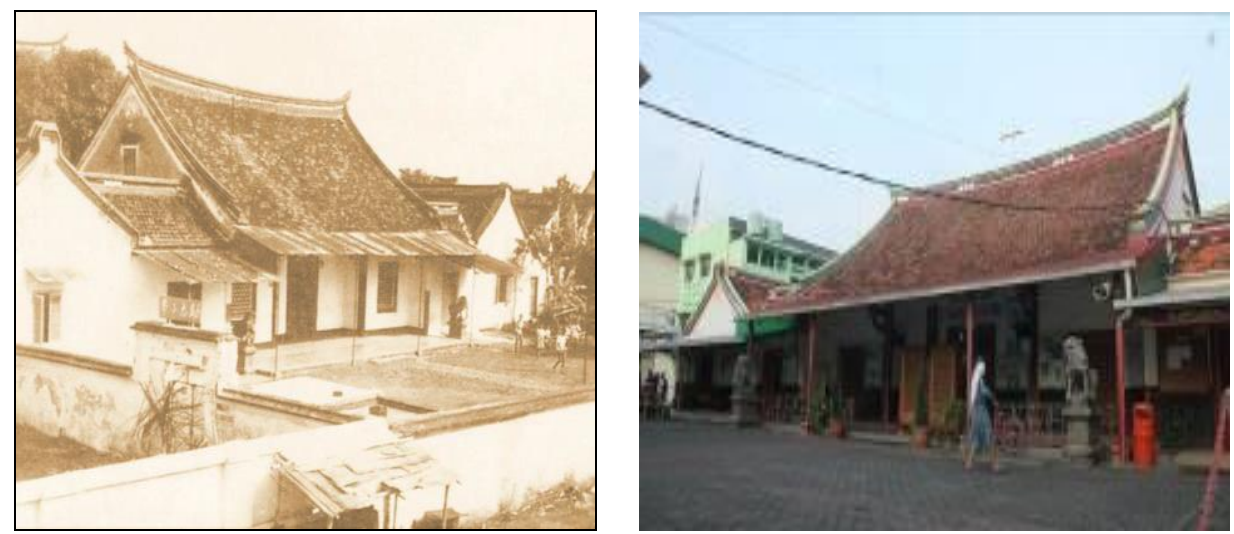

Gambar 8. Kondisi pada awal abad ke 20 M (Kiri), Kondisi pada saat ini sebagai salah satu bangunan langgam Cina yang dikunjungi wisatawan (Kanan).

\section{Pusat Kegiatan Profan}

Dalam konteks budaya, pusat-pusat aktivitas ekonomi bisa dikatakan destinasi wisata budaya dan living heritage. Beberapa pasar, jalan, atau gang di kawasan Pecinan Glodok masih menunjukkan karakter kawasan bagian dari Kota Tua Jakarta. Adapun beberapa destinasi tersebut adalah:

\section{Pusat-Pusat Aktivitas Ekonomi \\ Pasar Asemka}

Pasar Asemka terletak di Jalan Pintu Kecil, Kelurahan Roa Malaka, Kecamatan Tambora, Jakarta Barat. Pada abad ke 17-awal 18 M, di daerah ini terdapat pintu kecil (kleine port) untuk masuk Kota Batavia khusus bagi etnis Cina. Sedangkan nama dari Asemka, merupakan toponomi kawasan ini pada masa lalu kemungkinan banyak ditumbuhi oleh pohon asam jawa (Tamarindus indica). Pada awal tahun 
1920an hingga pasca kemerdekaan, daerah ini masih bernama Passer Pagi Straat atau Jalan Pasar Pagi (Vletter, Voskuil, \& Diessen, 1997).
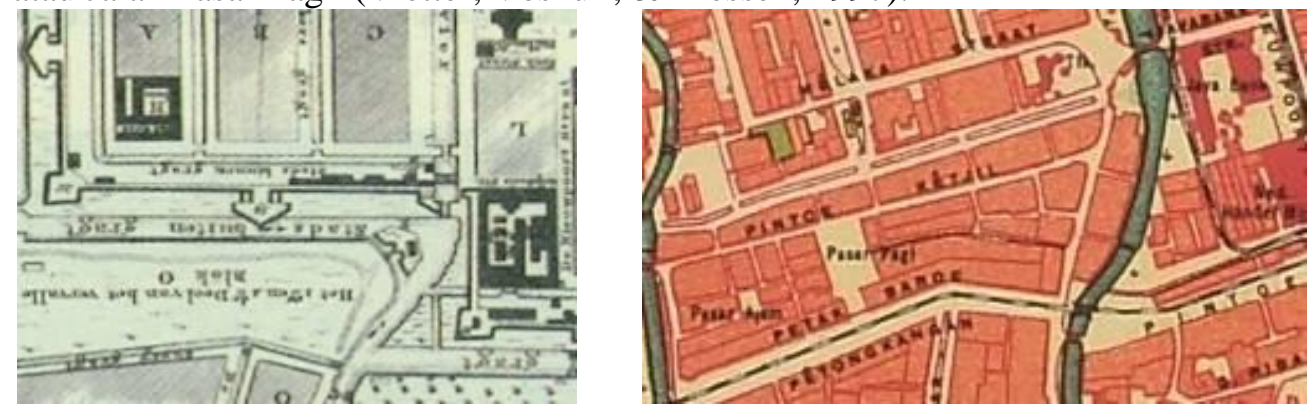

Gambar 9. Peta Kota Batavia Karya von Leupken tahun 1764 (Heuken, 2016:107) (Kiri), Kawasan Pasar Pagi dan Pintu Kecil pada Peta Batavia tahun 1921 (Diessen, J.R.Van, J.Ormeling, \& Braam, 2004) (Kanan).

Kawasan Pasar Pagi dan Pintu Kecil (Kleine Poort) merupakan daerah keluar masuk ke Kota Batavia di sisi selatan yang dibangun pada 1638, yang terletak di Kubu Bastion Diest, maka bernama Diestpoort, yang sudah dikenal sebagai pusat perdagangan di Batavia yang dekat dengan kawasan Pecinan (Het Chine Kwartier). Namun sejak perisitiwa kerusuhan Tionghoa 1740, banyak etnis Tionghoa ditempatkan di luar tembok kota. Pada awal tahun 1920an sudah dikenal sebagai pusat perdagangan di daerah Glodok dan Asemka. Hal ini terkait kebijakan pemerintah kolonial Belanda yang memberikan hak istimewa kepada kalangan Cina untuk membangun pemukimannya dengan segala bentuk kebudayaannya. Jalan Pasar Pagi dahulu dikenal dengan nama Passer Pagi.

Kini Pasar Asemka ramai dikunjungi oleh pembeli baik eceran maupun grosir dari berbagai tempat di Jakarta maupun dari luar Jakarta. Aktivitas pasar dimulai pagi hari hingga malam. Namun nama pasar pagi lebih terkenal karena pasar ini sudah ramai sejak pagi hari. Adapun di Pasar Pagi Asemka banyak dijual barangbarang seperti mainan anak-anak, garmen, peralatan sekolah, souvenir, dan pernakpernik lainnya. Pasar Pagi Asemka sangat ramai menjual pernak-pernik hari raya Imlek, Natal, pada saat menjelang hari raya tersebut.

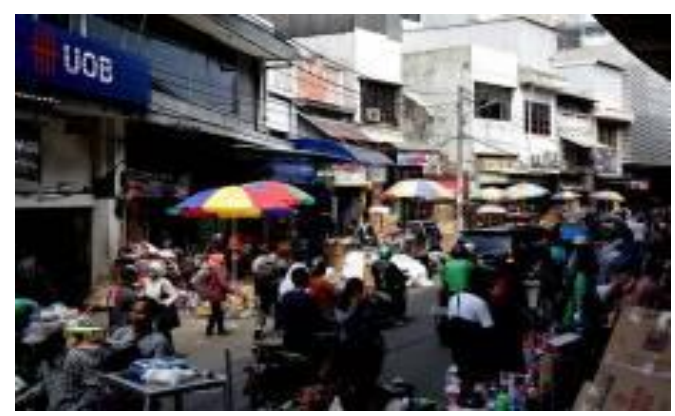

Gambar 10. Suasana Pasar Asemka dari Jalan Pasar Pagi (Ulfiana, 2018). 
Sejak masa lalu, Asemka selalu menjadi magnet bagi warga Ibu Kota dan sekitarnya. Transaksi di sana mulai tergerus oleh pertumbuhan e-commerce.

\section{Gang Gloria}

Gang Gloria terletak di Jalan Pintu Besar III, Kelurahan Pinangsia, Kecamatan Tamansari, Kota Jakarta Barat kode pos 11120. Gang Gloria terkenal akan tempat wisata kuliner khas Pecinan, baik yang dijajakan melalui kaki lima maupun di ruko-ruko. Di antaranya yang terkenal adalah kopi Tak Kie.
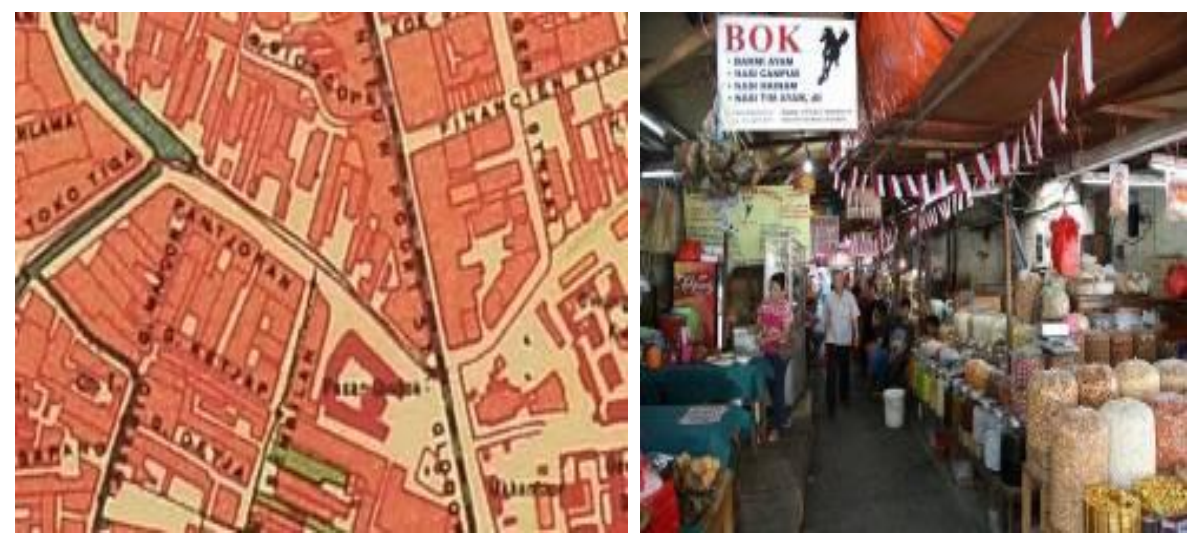

Gambar 11. Kawasan Pancoran dan sekitarnya pada Peta Batavia tahun 1921

(Diessen, J.R.Van, J.Ormeling, \& Braam, 2004).

Kawasan Pancoran tahun 1920an sudah terlihat merupakan pemukiman yang padat (warna merah). Dalam peta tersebut, kawasan gang Gloria dan sekitarnya masuk dalam kawasan dengan nama Pantjoran (kini Jalan Pancoran). Gang Gloria kini terkenal dengan beraneka ragam kuliner yang khas 'Cina', seperti bakmi, bakpao, bakcang, dan lain sebagainya. Bagi para peminat wisata halal, tidak disarankan untuk memasuki kawasan ini.

\section{Jalan Perniagaan Raya}

Jalan Perniagaan Raya terletak antara Jalan KH. Muh. Mansur di sisi barat, yang merupakan batas kawasan Pecinan dengan Pekojan dan Jalan Toko Tiga yang merupakan jalan ke arah kawasan Petak Sembilan. Pada masa lalu abad ke 17-18 M, kawasan ini merupakan salah satu pusat kawasan perdagangan karena kawasan ini merupakan jalur yang dilalui oleh Kali Angke, dimana Kali Angke memisahkan antara kawasan Pecinan yang dihuni oleh orang-orang etnis Tionghoa dan kawasan Pekojan $(\mathrm{Koja}=a r a b)$ yang merupakan kawasan yang dihuni oleh orang-orang dari Timur Tengah. Pada masa lalu, politik pemisahan etnis oleh Belanda.

Jalan Perniagaan Raya pada masa lalu terkenal dengan nama Jalan 'Patekoan'. Patekoan berasal dari bahasa Mandarin Hokkien bernama 'Pat' yang artinya delapan dan 'Teko' yang artinya teko atau tempat minum. Menurut cerita pada abad ke 17, hiduplah seorang Kapiten Cina Gan Djie bersama istrinya yang berasal dari Bali. Ia sering menyediakan minuman teh secara gratis kepada para 
pedagang, dan orang-orang yang lewat di jalan tersebut dengan jumlah delapan (8) teko di depan rumahnya.

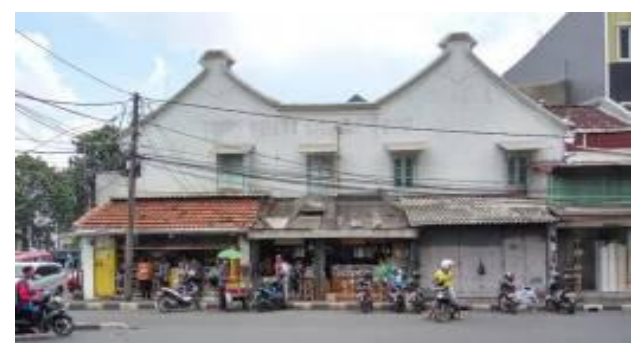

Gambar 12. Toko obat Lay An Tong di Jalan Perniagaan Raya, Salah satu toko obat 'Lay An Tong' yang masih ada di Jalan Perniagaan Raya. Kawasan ini juga terkenal dengan pusat pengobatan dan tabib Cina

\section{Jalan Jelangkeng}

Jalan Jelangkeng kini bernama Jalan Perniagaan Barat, namun orang-orang masih mengenal nama Jalan Jelangkeng. Jalan ini terletak sepanjang Kali Krukut dan Jalan Tambora VI dan VIII serta Jalan Perniagaan Raya. Sama seperti Jalan Perniagaan Raya, di Jalan Jelangkeng masih banyak ditemui toko-toko obat khas Cina, namun pada awal perkembangan kawasan abad ke 18, kawasan ini dikenal dengan daerah 'madat' karena di sini terdapat 26 ruko (shophouse) yang dipergunakan untuk menghisap opium dan kegiatan 'madat' lainnya.

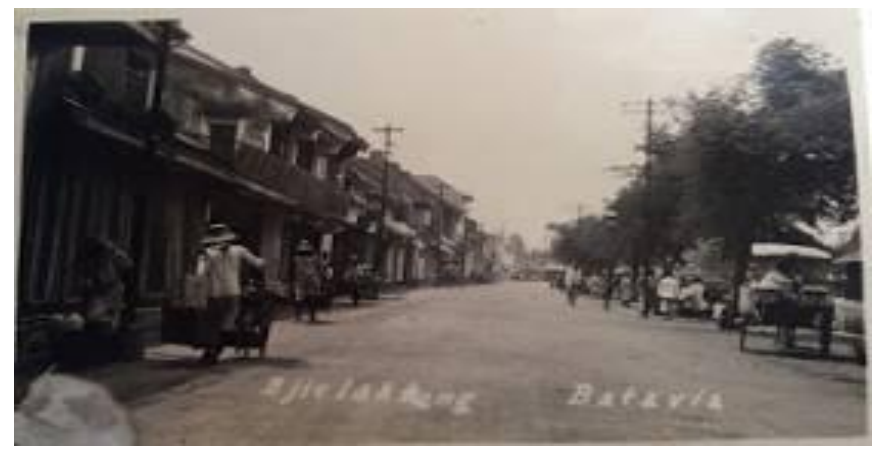

Gambar 13. Kondisi Jalan pada abad ke 19-awal 20 M, masih terlihat deretan ruko (shophouse) gaya Pecinan. Nama Jelangkeng berasal dari kata Djielakkeng (Surjadi, 2018)

\section{Pusat Kegiatan Lainnya}

\section{Sekolah Menengah Atas Negeri No.19}

Sekolah Menengah Atas Negeri No. 19 berlokasi di Jalan Patekoan (Jalan Perniagaan No. 31, Kelurahan Roa Malaka, Kecamatan Tambora, Jakarta Barat) ini terkenal dengan nama $\mathrm{Pa} \mathrm{Hua.} \mathrm{Sekolah} \mathrm{ini} \mathrm{dulunya} \mathrm{merupakan} \mathrm{tempat} \mathrm{lahirnya}$ perkumpulan Tionghoa Hwee Koan (THHK). Tionghoa Hwee Kwan atau Rumah Perkumpulan Tionghoa adalah sebuah organisasi yang didirikan pada tanggal 17 
Maret 1900 oleh beberapa tokoh keturunan Tionghoa di Batavia, yang tertujuan untuk mendorong orang Tionghoa yang bermukim di wilayah Hindia Belanda untuk mengenal identitasnya. Kegiatan utama THHK adalah membangun dan membina sekolah-sekolah berbahasa Mandarin, yang berlandasakan pada ajaran Konghucu. Berdirinya sekolah-sekolah Tionghoa Hwee Koan ini merupakan reaksi masyarakat Tionghoa di Batavia terhadap pemerintah Belanda, yang tidak pernah memberikan pendidikan anak-anak Tionghoa. Perkumpulan ini lebih dulu 8 tahun daripada organisasi kebangsaan Boedi Oetomo.

Dalam tulisannya Herman Tan (2018) menyatakan bahwa sampai abad ke 20, istilah CIna masih lazim digunakan untuk menyebut Tiongkok dan Tionghoa. Sebutan itu digunakan oleh Tionghoa maupun non-Tionghoa sendiri. Waktu itu kata 'Cina' sendiri belum mengandung arti/bermakna penghinaan. Persoalan mulai timbul ketika pergerakan kaum nasionalis di Tiongkok bangkit untuk menggulingkan kekaisaran Dinasti Qing dan memperkenalkan istilah Tionghoa. Hal ini juga mempengaruhi orang-orang Tionghoa di Indonesia untuk mendirikan Tiong Hoa Hwee Koan Hanzi: 中华会馆; Pinyin: Zhonghua Huiguan (Tan, 2018). Pasca peristiwa G30S/PKI, sekolah-sekolah berbahasa Tionghoa termasuk THHK ditutup oleh pemerintah Orde Baru.
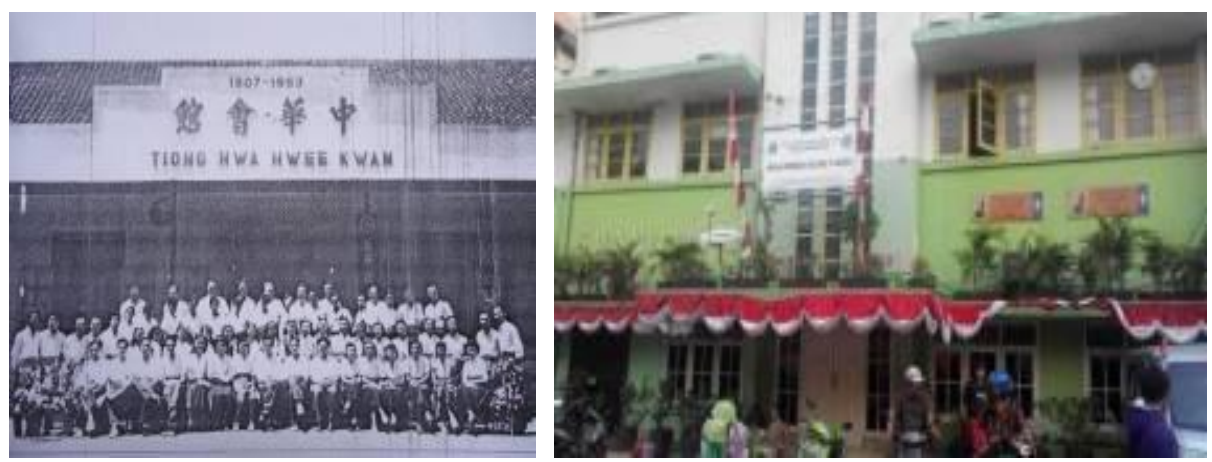

Gambar 14. Tampak foto bersama sebagian lulusan alumni sekolah Tiong Hoa Hwee Koan tahun 1953 (Tan, 2018) (Kiri), Tampak depan gedung SMA N 19 Jakarta sebagai tempat lahirnya organisasi THHK (Tan, 2018) (Kanan).

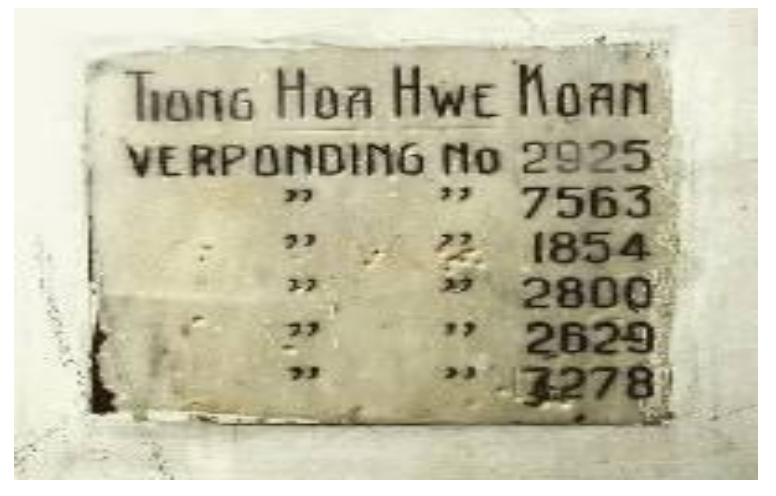


Gambar 15. Bukti tagihan pajak (Eigendom Verponding/EV) yang dikenakan oleh pemerintah Kolonial Belanda atas tanah atau bangunan di abad ke 19-20 M. Nomor

EV ini masih bisa dilihat di bagian belakang gerbang SMA N 19 Jakarta Barat.

\section{Rumah Keluarga Souw}

Bangunan ini terletak di Jalan Perniagaan Raya, Kelurahan Roa Malaka, Kecamatan Tambora, Jakarta Barat. Keberadaan bangunan ini mengukuhkan adanta pemukiman khusus untuk etnis Cina dan memiliki keterkaitan dengan kebijaksanaan penguasa VOC/Pemerintah Kolonial Hindia Belanda yang memberikan hak istimewa kepada kalangan Cina untuk membangun pemukimannya dengan segala bentuk kebudayaannya (Dinas Kebudayaan dan Permuseuman DKI Jakarta dan PDA, 2004).

Rumah ini tergolong sebagai rumah tripartit. Rumah tripartit adalah kompleks dengan tiga (tri-) rumah induk yang dipisah oleh kebun di antaranya. Hal ini lazim di daearh Tiongkok Selatan (Heuken, 2016), yang dibangun oleh 'Letnan' Souw Tian Pie, yang nenek moyangnya sudah beberapa abad tinggal di Batavia (Heuken, 2016). Keluarga Souw dulu terkenal sebagai keluarga kaya raya dan pernah menjabat sebagai liutenant der Chinezeen. Anggota Souw yang terkenal adalah kakak-beradik Souw Siauw Tjong (masa jabatan 1848-1860) dan Souw Siauw Keng (masa jabatan 1897-1913). Kakek buyut dan ayah mereka bernama Souw Kong Seng (1766-1821) dan Souw Thian Pie (1816-1870) pernah menjabat sebagai liutenant der Chinezeen. Souw Siauw Tjong dikenal sangat dermawan, ia banyak membantu klenteng-klenteng tua. Salah satunya saat memugar Klenteng Boen Tek Bio di Tangeran tahun 1875 dan Klenteng Kim Tek Ie Batavia tahun 1890. Saudara Souw Siauw Tjong, Souw Siaw Keng diangkat menjadi liutenant der Chinezeen di Tangerang pada tahun 1884. Souw Siauw Tjong merupakan salah satu orang terkaya di Batavia pada saat itu, memiliki tanah yang luas di Paroeng Koeda, Kedawoeng Oost (Wetan), dan Ketapang yang kini berada di wilayah Tangerang, Banten (http://nasional.kompas.com/read/2010/02/23/09014881/warisan.souw.di.patekoan).

Rumah ini terdiri dari tiga gedung utama dipisahkan oleh taman. Sebelah kanan dan kiri seluruh kompleks dibatasi oleh rumah panjang yang digunakan oleh para selir, tamu, pembantu, dan gudang. Pada tahun 1980 bagian barat didirikan Pasar Perniagaan, Jakarta Barat (Heuken, 2016).
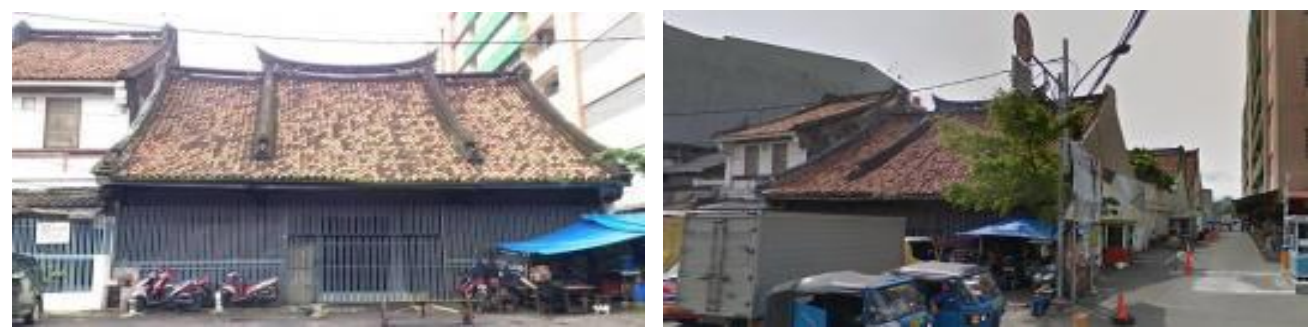

Gambar 16. Tampak depan rumah keluarga Souw (Kiri), Tampak samping rumah keluarga Souw (Kanan). 


\section{SIMPULAN}

Kawasan Pecinan Glodok di Jakarta Barat banyak terdapat historical-site attraction atau destinasi wisata sejarah seperti pusat-pusat aktivitas sakral (klenteng/vihara, dan gereja), maupun pusat kegiatan profan (pasar, jalan/gang, dan lainnya). Oleh karena itu pengembangan ke depan harus mengacu kepada UU No. 11 Tahun 2010 tentang Cagar Budaya bahwa pemanfaatan cagar budaya harus didasarkan pada perlindungan dan pengembangan bukan sebaliknya. Sehingga diharapkan kegiatan pariwisata berbasis pelestarian di kawasan Pecinan Glodok dapat bertahan (sustain) dengan baik, tanpa ada perubahan yang tentunya merusak elemen keasliannya (authenticity) sebagai kawasan pecinan di Jakarta dan Indonesia pada umumnya.

\section{DAFTAR PUSTAKA}

Ashworth, G., \& Turnbridge, J. (2000). The Tourist-Historic City: Retrospect and Prospect of Managing the Heritage City. Oxford: Elsevier Science.

Creswell, John W., (2014). Qualitative, Quantitative, and Mix-Method Approaches. California: SAGE Publication

Diessen, J.R.Van, J.Ormeling, F., \& Braam, R. (2004). Grote Atlas van Nederlands Oost-Indie: Comprehensive Atlas of The Netherlands East Indies. Zierikzee: Asia Maior

Dinas Kebudayaan dan Permuseuman DKI Jakarta dan Pusat Dokumentasi Arsitektur, (2004). Pembuatan dan Informasi Bangunan Cagar Budaya Guna Menyempurnakan SK Gubernur No. 475/1993. Jakarta.

Heuken, A. (2016). Tempat-Tempat Bersejarah Di Jakarta. Jakarta: Yayasan Cipta Loka Caraka.

Heuken, Adolf, (2003). "Gereja-Gereja Tua di Jakarta," dalam Gedung-Gedung Ibadat Yang Tua Di Jakarta. Jakarta: Yayasan Cipta Loka Caraka (edisi kedua).

Koentjaraningrat. (2002). Pengantar Ilmu Antropologi. Jakarta: Rineka Cipta.

Lombard, D. (2005). Nusa Jawa Silang Budaya: Warisan Kerajaan-Kerajaan Konsentris . Jakarta: Gramedia Pustaka Utama.

Pasquinelli, C., \& Bellini, N. (2017). Global Contex, Policies and Practices in Urban Tourism: An Introduction. In N. Bellini, \& C. Pasquinelli, Tourism in the City Toward and Integrative Agenda on Urban Tourism (p. 5). Switzerland: Springer International Publishing. 
Purbakala, D. (2000). Kelenteng Kuno di DKI Jakarta dan Jawa Barat. Jakarta: Direktorat Purbakala, Kementerian Pendidikan dan Kebudayaan.

Sulistyo, Ary, (2015). Menyoal Kembali Branding City Kota Depok Sebagai Kota Pendidikan: Sebuah Pandangan Retrospektif. Dalam https://iplbi.or.id/menyoal-kembali-branding-city-kota-depok-sebagai-kotapendidikan-sebuah-pandangan-retrospektif/. Diakses 26 Maret 2019

Surjadi, J. (2018, June Wednesday). Nama Jalan di Batavia berdasarkan Kartu. Dalam http://dedjadoel.blogspot.com/2018/06/nama-jalan-di-bataviaberdasarkan-kartu.html. Diakses tanggal 14 Maret 2019.

Salmon, Claudine dan Denys Lombard, (2003). Klenteng-Klenteng Masyarakat Tionghoa di Jakarta. Jakarta: Yayasan Cipta Loka Caraka (edisi kedua).

Tim Direktorat Purbakala, (2000). Kelenteng Kuno di DKI Jakarta dan Jawa Barat. Jakarta: Direktorat Purbakala, Kementerian Pendidikan dan Kebudayaan.

Thaib, H. S. (2016). Indonesia's 10 New Bali. The 3rd Joint Working Group Meeting Indonesia and France. Jakarta: Kementerian Pariwisata.

Ulfiana, A. D. (2018, Desember Tuesday). Katadata. dalam https://katadata.co.id/foto/2018/12/11/pernak-pernik-natal. Diakses tanggal 14 Maret 2019.

Vletter, M. d., Voskuil, R., \& Diessen, J. v. (1997). Batavia/Djakarta/Jakarta Beeld van een metamorfose. Purmerend: Asia Maior

Wardhani, A.D., 2012. Evolusi Aktual Aktivitas Urban Tourism di Kota Bandung dan Dampaknya Terhadap Pembentukan Tempat-Tempat Rekreasi. Dalam Jurnal Pembangunan Wilayah dan Kota, Vol 8 (4): 371-382, Desember 2012. Biro Penerbit Undip, Semarang.

Yoeti, O. A. (1996). Pariwisata Berbasis Budaya: Masalah dan Solusi. Jakarta: Pradnya Paramita. 